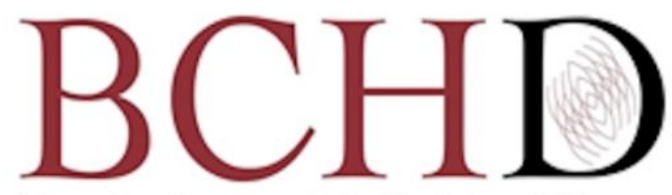

Bioactive Compounds in Health and Disease

\title{
Bioactive components of two species of locally grown nuts: Their potential health benefits and implications for healthy living
}

\author{
Ayomadewa Mercy Olatunya
}

Department of Chemistry, Ekiti State University, Ado Ekiti, Nigeria. P.M.B, 5363, Ado Ekiti, Nigeria

Corresponding Author: Ayomadewa Mercy Olatunya, Department of Chemistry, Ekiti State University, Ado Ekiti, Nigeria. P.M.B, 5363, Ado Ekiti, Nigeria

Submission Date: November 30th 2021 ; Acceptance Date: December 22 ${ }^{\text {nd }}, 2021$; Publication Date: December $28^{\text {th }}, 2021$

Please cite this article as: Olatunya A.M. Bioactive components of two species of locally grown nuts: Their potential health benefits and implications for healthy living. Bioactive Compounds in Health and Disease 2021; 4(12): 301-310. DOI: https://www.doi.org/10.31989/bchd.v4i12.869

\section{ABSTRACT}

Background: Bioactive compounds are naturally occurring compounds in plants and animal products. They are known to have a variety of physiological functions in the body system such as: promoting general body development and prevention of the occurrence of some deadly diseases. The high burden of treatment of some deadly diseases like cancer, high blood pressure, and cardiovascular diseases has raised the need for scientists to generate empirical evidence on preventing these diseases using a dietary approach. Nuts have been identified as plants with potential to improve human health and prevent diseases when consumed adequately because of their rich constituents. This research work was conducted to evaluate and elucidate the bioactive components of locally grown nuts and their potential health benefits.

Methods: The Phenolic compounds, phytosterols, tocopherols, and tocotrienols contents of the nuts were analyzed using standard methods.

Results: Fourteen phenolic compounds were detected in the two nuts with cinnamic and gallic acids detected in appreciable amounts in groundnuts and caffeic acid in cashew nut. The total amount of tocopherols in cashew nut was $14.08 \mathrm{mg} / 100 \mathrm{~g}$ and $37.95 \mathrm{mg} / 100 \mathrm{~g}$ in groundnut and the total tocotrienol was 0.85 and $4.00 \times 10^{-3} \mathrm{mg} / 100 \mathrm{~g}$ for cashew nut and groundnut respectively. Both samples have high quantity of sistosterol $(251.36 \mathrm{mg} / 100 \mathrm{~g}$ and $238.95 \mathrm{mg} / 100 \mathrm{~g}$ for cashew nut and groundnut respectively) with cashew nut having significantly higher amount. 
Conclusion: The results showed that the nuts are rich in bioactive compounds and could be considered as natural sources of bioactive compounds that can be obtained from diets rich in these nuts to prevent the occurrence of certain deadly human diseases that are of high burden worldwide.

Keywords: Phenolic Compounds, Tocopherols, Groundnuts, Cashew nuts
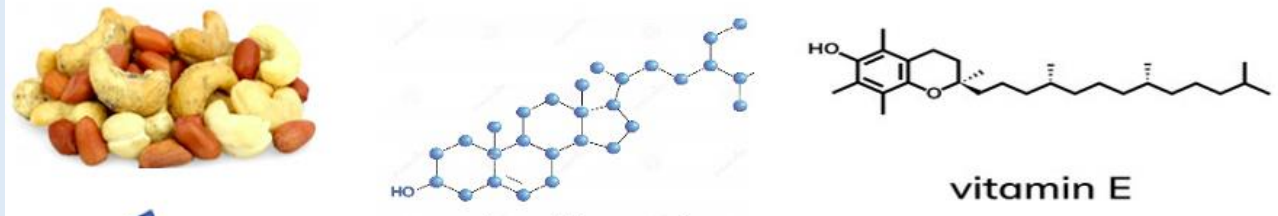

Phenolic compounds



beta-Sitosterol

vitamin $\mathrm{E}$

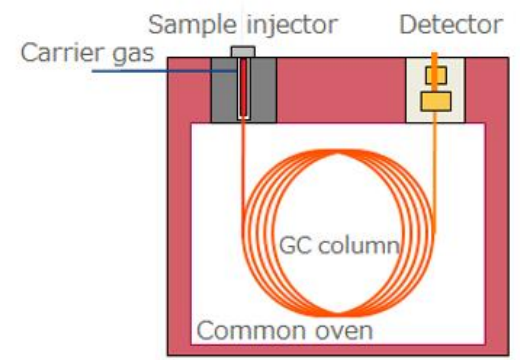

CFFC 2021. This is an Open Access article distributed under the terms of the Creative Commons Attribution 4.0 License (http://creativecommons.org/licenses/by/4.0)

\section{INTRODUCTION}

Bioactive compounds are chemical compounds found in certain foods with proven or potential health benefits. They are naturally occurring compounds in plants and animal products and are known to have a variety of physiological functions for promoting general body development and disease prevention [1]. They can be found in fruits, vegetables, and in nearly every plant structure. Some examples of bioactive compounds include phenolic compounds, polyphenols, lignans, phytosterols and stilbenoids [1].

Bioactive compounds are typically present in very small quantities but seem to provide powerful health benefits in relation to their concentration in the food matrix. They are produced from plants mainly used for medicinal purposes and act on different systems of animals including man [2]. Different types of bioactive substances such as polysaccharides, pigments, minerals, peptides, and polyphenols, which have valuable pharmaceutical and biomedical potential have been found in plants. Even though these bioactive substances are present in virtually all plant foods, their levels vary enormously among diets depending on the plant's type and quantity of such plant in food diets. Phenolic compounds, commonly referred to as polyphenols, are present in all plants and, thus, could be obtained from diets containing such plants. There are 8,000 phenolic structures that have been identified and they vary 
structurally from being simple molecules (e.g., phenolic acids with a C6 ring structure) to being highly polymerized compounds like tannins [3]. Another example of bioactive compounds is phytosterols which are plant sterols that occur naturally in the unsaponifiable fraction of plant oils. They are present in low amount in human tissues because they are not synthesized in human and are poorly absorbed [4] thus they are better obtained from nutrition and diets from plants sources. Phytosterols have been found to have numerous health benefits. For example, they lower absorption of unhealthy cholesterol levels in human and are also useful in prevention of cardiovascular heart diseases [4].

Chemoprevention involves the use of drugs, vitamins, or nutritional supplements to reduce the risk of developing or having a recurrence of some diseases including cancer. The consumption of whole plant foods as chemo-preventive agents is highly recommended in the dietary guidelines because of the health benefits from dietary phytochemicals present in them that have been observed in epidemiological studies [5]. Therefore, there is the need to conduct much scientific research on potential sources of bioactive compounds to be able to make science - based dietary recommendations rich in bioactive compounds from plant sources because quite a few bioactive compounds appear to have beneficial health effects.

Fruits, vegetables, and nuts play important roles in human nutrition; they are sources of vitamins, minerals, and fiber [6]. A daily intake of $30 \mathrm{~g}$ per day of nuts is recommended to protect human health [6]. Groundnut (Arachis hypogaea), generally known as peanut, is an important food and is known as one of the most important oil seed crops in the world [7] because it has high concentration of edible nutrients. Groundnut belongs to the legume family and is one of the major sources of edible oil and food in Nigeria. They are nutritious and rich in oil; thus, they are good sources of nutrients worldwide [7]. Fatty acids present in groundnut have been found to demonstrate beneficial effects on the cardiovascular system [8]. They also have antiinflammatory properties, which are mainly attributed to their ability to modify prostaglandin and lipid synthesis [7]. Their anti-inflammatory properties and fatty acid components protect against heart diseases in human [78].

Cashew (Anacardium occidentale) is popularly used worldwide in making sweet and savory dishes. It belongs to the Anacardiaceae family, of the genus Anacardium. Cashew fruit has an oval shaped seed attached to it which contains nuts that are generally eaten as snacks after processed. Cashew nuts are rich in nutrients and beneficial plant compounds and so, they help to improve the health conditions of humans. Cashews are rich sources of polyphenols and carotenoids. Consumption of the nuts have been linked to benefits like weight loss, improved blood sugar control, and a healthier heart [9]. Some authors have found that nuts are rich sources of fatty acids, carbohydrates, protein, fat, and vitamins [7, 10]. They have also been found to help in providing protection against certain deadly diseases like coronary heart disease [11]. Due to the various beneficial effects of these nuts, and because of the growing interest in evaluating their roles in a healthy diet, there is a need to research more on the hidden benefits that could be derived from these nuts. Thus, this research focuses on evaluating and comparing the bioactive components present in two locally grown nuts, with the aim of highlighting their potential health benefits to humans. This will help provide evidence to show the need for regular consumption of these nuts for prevention of deadly diseases that can be prevented through diet. This would be helpful due to the high burden of treatment of 
such diseases worldwide. This research is very apt, especially for the less developed parts of the world where the burdens of poverty can impact preventable human diseases.

\section{MATERIALS AND METHODS}

The groundnut and cashew nut were collected from local markets around Ado - Ekiti metropolis of Ekiti State Nigeria. All chemicals used were of analytical grade and purchased from Sigma Aldrich, Germany. The samples were washed thoroughly and air-dried, after which the samples were ground using electrical grinder.

Extraction of oil: About 150g of the powdered samples of each seed flour was weighed and extracted in Soxhlet extractor using diethyl ether for 5 hours at a temperature of $40-50^{\circ} \mathrm{C}$. After extraction, the oil was concentrated using rotary evaporator (Rotavapor R110, Buchi laboratoriums- Technik AG).

Determination of phenolic compounds: $50 \mathrm{mg}$ of the extracted oil was reacted with $5 \mathrm{ml}$ of $1 \mathrm{M} \mathrm{NaOH}$ on orbital shaker at ambient temperature for 16 hours as described by Provan et al. [12] with slight modification. The sample was then centrifuged, rinsed with water, centrifuged again and the supernatants were combined and placed in a disposable glass test tube and heated at $90^{\circ} \mathrm{C}$ for 2 hours to release the conjugated phenolic compounds. The heated extract was cooled, titrated with $4 \mathrm{M} \mathrm{HCl}$ to $\mathrm{pH}$ less than 2.0 diluted to $10 \mathrm{ml}$, with deionized water and then centrifuged to remove the precipitate. The supernatant was analyzed using gas chromatography. The gas chromatography equipment and conditions: Hewlett-Packard Packed 6890 Gas Chromatograph (Agilent Technologies, Inc.,Wilmington, $\mathrm{DE}$, USA) column length - 30m, injection temperature $250^{\circ} \mathrm{C}$, detector - flame ionization detector, carrier gas - nitrogen, initial temp $-60^{\circ} \mathrm{C}$ for $5 \mathrm{~min}$, first rate $-15^{\circ} \mathrm{C}$ for $15 \mathrm{~min}$ and second rate $-10^{\circ} \mathrm{C}$ for $4 \mathrm{~min}$.

Determination of tocopherols and tocotrienols: To quantify the tocols in the seed oils, the methods of Du and Ahn [13] and Ahsan et al. [14] were used with slight modifications. $100-150 \mathrm{mg}$ of oil samples were weighed into $50 \mathrm{ml}$ Erlenmeyer flasks and esterified with $10 \mathrm{ml}$ of a freshly prepared mixture containing ethanol, $33 \% \mathrm{KOH}$ solution, and ascorbic solution (to prevent oxidation of the tocols during esterification). Sample were homogenized and incubated at $50^{\circ} \mathrm{C}$ for 1 hour, $5 \mathrm{ml}$ each of deionized water and redistilled hexane was added. The mixture was then thoroughly shaken and allowed to stand for about 15 hours for the phase to separate. After phase separation, the unsaponifiable matter was transferred to a scintillation vial under nitrogen. To derive tocopherols, pyridine, and a mixture of $99 \%$ bistri fluoro acetamide and trimethyl chlorosilane were added and to derive tocotrienols, trimethyl siliane was added. 2 $\mathrm{ml}$ of internal standard solution and $7 \mathrm{ml}$ of hexane were added, and the lipids were derived overnight at room temperature before analysis by gas chromatography (GC). The GC equipment was the same as described above. The conditions were as follows: The capillary column used was $30 \mathrm{~m} \times 0.25 \mathrm{~mm} \times 0.25 \mu \mathrm{m}$ for tocopherol and $15 \mathrm{~m} \times 0.25 \mathrm{~mm} \times 0.15 \mu \mathrm{m}$ supported on $\mathrm{BaCO}_{3}$ for tocotrienol, initial temperature $180^{\circ} \mathrm{C}(10 \mathrm{~min})$; increased from $8^{\circ} \mathrm{C} / \mathrm{min}$ to $260^{\circ} \mathrm{C}$, then to $280^{\circ} \mathrm{C}$ at $2^{\circ} \mathrm{C} / \mathrm{min}$, maintained at $13 \mathrm{~min}$. The injector and detector temperatures were $290^{\circ} \mathrm{C}$ and $300^{\circ} \mathrm{C}$, respectively. Helium was used as the carrier gas at a flow rate of 1.2 and $2.5 \mathrm{~mL} / \mathrm{min}$ for tocopherols and tocotrienols, respectively. Peak areas were measured using a HewlettPackard Packard 7860 integrator (Agilent Technologies, Inc.). 
Determination of phytosterol content: The composition of the phytosterols was determined according to the method of the International Organization for Standardization [15]. Approximately $250 \mathrm{mg}$ of oil, saponified with an ethanolic potassium hydroxide solution was added to $1 \mathrm{ml}$ of internal standard solution; the unsaponifiable fraction was isolated by solid-phase extraction on an aluminum oxide column, and the steroid fraction was obtained after thin layer chromatography. Bands were visualized using $n$-hexane/diethyl ether (1:1, $\mathrm{v} / \mathrm{v}$ ) as the developing solvent. The sterol profile was analyzed using GC analysis as described for phenolic acid determination above with little differences such as carrier gas - Nitrogen at a flow rate of $35 \mathrm{~mL} / \mathrm{min}$ and a pressure of $22 \mathrm{psi}, 1 \mathrm{ml} / \mathrm{min}$. The injector and detector temperatures were $250^{\circ} \mathrm{C}$ and $320^{\circ} \mathrm{C}$, respectively, and the oven was programmed to decrease in temperature from 60 to $15^{\circ} \mathrm{C}$ at $4^{\circ} \mathrm{C} / \mathrm{min}$. The injection volume was 1 $\mathrm{ml}$, with a split ratio of 20:1. The total sterol content was determined by considering all peaks of sterols eluted between cholesterol and $\Delta 7$-avenasterol. Peaks were identified by comparing the relative retention times of samples with those obtained from standards.

Statistical Analysis: All values were expressed as means of triplicate analysis. Correlation paired t test and MannWhitney test was performed using GraphPad Prism program version 5 for windows and differences among the means were determined for significance at $p<0.05$.

\section{RESULTS AND DISCUSSION}

Phenolic compounds: Fourteen phenolic compounds were detected in the two investigated nuts (Table 1). Caffeic acid was present in appreciable amounts in cashew nut, while cinnamic acid and gallic acid were detected in appreciable amounts in groundnut.
Groundnut has a significantly higher amount of total phenolic compounds than cashew nut. All classes of phenolic compounds have various biological functions. For example, gallic acid has been found to have numerous health benefits; it acts as a preservative in the food industry, it is useful in ameliorating occurrences of certain diseases like cardiovascular and intestinal diseases [16-17]. Also, cinnamic acids have been found to have good antifungal and antibacterial activities [18]. Likewise, protocatechuic acid (PCA) has been found to have beneficial effects on osteoblast and osteoclast cells in vitro [19] hence, useful for bone health. Furthermore, consumption of caffeic - rich foods has been found to lead to having a protective effect against carcinogenesis by preventing the formation of nitro compounds (nitrosamines and nitrosamides) that are the main inducers of this pathology [20-21]. The phenolic compound of peanut reported in this present work is comparable to the reports of Sales and Resurreccion [22] that reported the presence of caffeic acid, $p$-coumaric acid, and Ferulic acid as the major phenolic compounds detected in peanut kernels.

The availability of the phenolic compounds in these nuts show they could serve as sources for these compounds in the human body system when adequately consumed. Furthermore, the nuts are cheap and readily available. Of note, is the presence of cinnamic, gallic and caffeic acids in appreciable amounts in these nuts thus, regular consumption of these nuts could help to supply these phenolic compounds into the human body system, thereby protecting the system against occurrence of certain deadly diseases. This is more important for the less developed parts of the world, where the burden of preventable human diseases is high, and there is a dearth of resources to combat them due to the many competing needs and inadequate fund availability in these settings. 
Table 1. Phenolic compounds content of composition of the two nuts

\begin{tabular}{|l|l|l|}
\hline Phenolic compounds & Cashew nut $(\mathrm{mg} / 100 \mathrm{~g})$ & Groundnut $(\mathrm{mg} / 100 \mathrm{~g})$ \\
\hline Salicyclic Acid & $3.74 \times 10^{-2}$ & $2.99 \times 10^{-3}$ \\
\hline Protocatechuic acid & $1.33 \times 10^{-3}$ & $1.35 \times 10^{-3}$ \\
\hline O- coumaric & $3.34 \times 10^{-1}$ & $9.27 \times 10^{-4}$ \\
\hline Vanillic acid & $1.63 \times 10^{-4}$ & $1.76 \times 10^{-4}$ \\
\hline p- hydroxybenzoic & $1.28 \times 10^{-2}$ & $3.40 \times 10^{-3}$ \\
\hline Cinnamic acid & $4.28 \times 10^{-2}$ & 1.00 \\
\hline Gallic acid & $2.12 \times 10^{-3}$ & 2.24 \\
\hline Caffeic acid & 1.78 & $1.32 \times 10^{-2}$ \\
\hline Ferulic acid & $2.15 \times 10^{-3}$ & $2.32 \times 10^{-1}$ \\
\hline Syringic acid & $2.17 \times 10^{-3}$ & $2.23 \times 10^{-3}$ \\
\hline Ellagic acid & $2.25 \times 10^{-3}$ & $2.24 \times 10^{-3}$ \\
\hline Piperic acid & $7.18 \times 10^{-7}$ & $7.05 \times 10^{-7}$ \\
\hline Sinapinic acid & $3.13 \times 10^{-6}$ & $5.06 \times 10^{-6}$ \\
\hline Chlorogenic acid & $7.03 \times 10^{-3}$ & $4.35 \times 10^{-3}$ \\
\hline Total & 2.22 & 3.50 \\
\hline
\end{tabular}

Table 2. Tocopherols and tocotrienol composition of the nuts

\begin{tabular}{|l|l|l|}
\hline Tocopherols & Cashew nut $(\mathrm{mg} / \mathbf{1 0 0 g})$ & Groundnut $(\mathrm{mg} / 100 \mathrm{~g})$ \\
\hline $\boldsymbol{\alpha}$ tocopherols & $3.59^{\mathrm{a}}$ & $23.70^{\mathrm{b}}$ \\
\hline $\boldsymbol{\gamma}$ tocopherols & $9.83^{\mathrm{a}}$ & $9.78^{\mathrm{b}}$ \\
\hline $\boldsymbol{\beta}$ tocopherols & $5.29 \times 10^{-2 \mathrm{a}}$ & $7.15 \times 10^{-1 \mathrm{~b}}$ \\
\hline $\boldsymbol{\delta}$ tocopherols & $6.09 \times 10^{-1 \mathrm{a}}$ & $3.75^{\mathrm{b}}$ \\
\hline Total & 14.08 & 37.95 \\
\hline Tocotrienols & & \\
\hline $\boldsymbol{\alpha}$ tocotrienols & $3.49 \times 10^{-1 \mathrm{a}}$ & $1.51 \times 10^{-3 \mathrm{~b}}$ \\
\hline $\boldsymbol{\gamma}$ tocotrienols & $5.03 \times 10^{-1 \mathrm{a}}$ & $2.49 \times 10^{-3 \mathrm{~b}}$ \\
\hline $\boldsymbol{\beta}$ tocotrienols & $4.11 \times 10^{-5 \mathrm{a}}$ & $3.33 \times 10^{-6 \mathrm{~b}}$ \\
\hline $\boldsymbol{\delta}$ tocotrienols & $1.31 \times 10^{-5 \mathrm{a}}$ & $4.39 \times 10^{-7 b}$ \\
\hline Total & 0.85 & $4.00 \times 10^{-3}$ \\
\hline Total Vitamin E & $\mathbf{1 4 . 9 3}$ & 37.95 \\
\hline
\end{tabular}

Means followed by different letters within each row indicates significant difference $p<0.05$

Tocopherols and Tocotrienols: All classes of tocopherol were detected in the two nuts. Groundnut has significantly higher amount of $\alpha$ - tocopherol and $\delta$ tocopherol. Cashew nuts have higher total tocotrienols than groundnut while the total vitamin $E$ content is significantly higher in groundnut (Table 2). Low levels of vitamin $\mathrm{E}$ in the human nutrition could be associated with a potentially higher risk of atherosclerosis or other degenerative diseases [23]. It has also been linked to the occurrence of cardiovascular heart diseases. The availability of each class of tocopherols and tocotrienols in these nuts is noteworthy because individual tocols have specific functions. For instance, $\alpha$-Tocopherol has a main function of being a radical chain breaking 
antioxidant in membranes, lipoproteins and in foods. It helps in cell proliferation, inhibition of platelet aggregation, and monocyte adhesion. It protects the body against degenerative malfunctions particularly cancer and cardiovascular diseases and are better at scavenging reactive oxygen species thereby having the best protection against fat oxidation and human diseases related to these [24].

Likewise, $\gamma$ tocopherol has been found to act as an anti-inflammatory agent, it aids in cell signaling and can lower cancer risk [25]. Both tocopherols and tocotrienols have been reported to kill breast cancer cell lines through apoptosis and reduce tumor cells in animals thus, they are useful in reducing the risk of breast cancer [26]. These vitamin Es also play roles in monocyte production which are large white blood cells that fight against viruses and harmful bacteria [27].

Therefore, the high quantity of tocopherols in these nuts (most especially groundnut) and the availability of all classes of vitamin $E$ in the nuts showed they could be good sources of essential nutraceuticals and can provide the body with the different classes of this important vitamin E when consumed. That commercially available vitamin E supplements mostly contain only $\alpha$-tocopherol provided as either unesterified or usually as the ester of acetate, succinate, or nicotinate [28] further reinforces the advantage of consuming these nuts. Also, it is generally agreed that vitamin $\mathrm{E}$ is safer and more beneficial when consumed through natural plants sources as food because they are fat soluble and not readily eliminated from the human body in cases of accidental excessive intake, which could readily occur through consumption of artificial or processed sources. Little wonder the American Heart Association (AHA) recommends obtaining antioxidants including vitamin $\mathrm{E}$ by eating a well-balanced diet high in fruits, vegetables and whole grains, rather than from supplements [29]. Therefore, the nuts in the current study, which are also good dietary sources of $\alpha$-, $\beta$ - and $\gamma$-tocopherol, can serve as sources of vitamin $E$ to the body system when consumed in adequate amount. The vitamin E content of peanuts reported in this work is comparable to the reports of Silva et al. [30], while that of cashew nuts is higher when compared to the report of Rico et al. [31] but lower to the report of Ryan et al. [10]. Also, the vitamin E content of the nuts reported in the present work is higher when compared to the report of Kornsteiner et al. [23]. The discrepancies in these reports may be because of differences in geographical locations of the samples.

The recommended dietary allowance (RDA) of vitamin $\mathrm{E}$ for adult age $14-51^{+}$is $15 \mathrm{mg}$, [32] and because these tocols are only biosynthesized in photosynthetic organisms, it is essential for human beings to acquire them from diets to meet the vitamin E requirements [33]. Therefore, consumption of about $100 \mathrm{~g}$ of cashew nut and $50 \mathrm{~g}$ of groundnut will adequately provide the recommended dietary allowance for vitamin E (Table 2 ).

Phytosterols: The two nuts have a high quantity of sistosterol but cashew nut has significantly higher value. The samples also have high quantity of campestrol with groundnuts having the highest value. Groundnut also has a high quantity of stigmasterol while 5 -Avenasterol was detected in appreciable amounts in the samples (Table 3). Phytosterols from the diet have been found to play a protective role in the development of some types of cancer like breast, colon, lung, stomach, and prostate [34]. Since these sterols cannot be synthesized in the body system, their consumption through diet is highly recommended. It has been found that a dose of 2- $4 \mathrm{~g}$ of phytosterol in a day can reduce low density lipoprotein cholesterol by approximately $10 \%$ [34-35]. Of note is the averagely high amount of sistosterol, campestrol and stigmasterol in the two samples. Also, the high total phytosterol of the samples showed that these nuts are rich sources of plant sterols therefore, consumption of 
about $60 \mathrm{~g}$ of these nuts will adequately supply a dietary intake of $150 \mathrm{mg}$ of phytosterols which can help in combating the occurrence of some of these diseases. The phytosterol contents of cashew nut evaluated in the present work is higher than the value reported by Rico et al. [31]. This further justifies the health importance of these nuts.
It will be interesting in the very near future if the use of these nuts is put into real time applications through randomized control trials on their beneficial effects in combating some prevalent human diseases as doing so will further drive home their health benefits and relevance.

Table 3. Phytosterol composition of the two nuts

\begin{tabular}{|l|l|l|}
\hline Phytosterols & Cashew nut $(\mathrm{mg} / \mathbf{1 0 0 g})$ & Groundnut $(\mathrm{mg} / 100 \mathrm{~g})$ \\
\hline Cholestanol & $3.50 \times 10^{-6}$ & $5.84 \times 10^{-6}$ \\
\hline Ergosterol & $3.41 \times 10^{-6}$ & $3.55 \times 10^{-6}$ \\
\hline Campesterol & $11.97^{\mathrm{a}}$ & $20.70^{\mathrm{b}}$ \\
\hline Stigmasterol & $1.65^{\mathrm{a}}$ & $11.99^{\mathrm{b}}$ \\
\hline 5 - Avenasterol & 1.66 & 2.30 \\
\hline Sistosterol & $251.36^{\mathrm{a}}$ & $238.95^{\mathrm{b}}$ \\
\hline Total & $\mathbf{2 6 6 . 6 4}$ & $\mathbf{2 7 3 . 9 4}$ \\
\hline
\end{tabular}

Means followed by different letters within each row indicates significant difference $p<0.05$

\section{CONCLUSION}

These nuts have a high quantity of bioactive components which have been found to be of great importance to humans when consumed. They are very rich in vitamin $E$, phytosterol and some phenolic compounds which are essential components that could only be supplied to the body from plant sources. Thus, consumption of these nuts would help to supply these bioactive compounds to the body system and help to prevent occurrence of certain deadly diseases which have been advocated to be prevented using diet rather than waiting for their manifestations and treatments.

Abbreviations: (AHA): American Heart Association, (RDA): recommended dietary allowance, (GC): gas chromatography, (PCA): protocatechuic acid

Funding Sources: The author did not receive any financial support for the research, authorship, and/or publication of this article

Conflict of Interest: The author declares no conflict of interest.

\section{REFERENCES}

1. Walia A, Gupta AK, Sharma V. Role of Bioactive Compounds in Human Health. Acta Sci Med Sci 2019, 3 (9): 25-33.

2. Loi M, Paciolla C, Logrieco AF, Mulè G. Plant Bioactive Compounds in Pre- and Postharvest Management for Aflatoxins Reduction. Front Microbol 2020, 11: 243. https://doi.org/10.3389/fmicb.2020.00243

3. Ozer HK. Phenolic compositions and antioxidant activities of Maya nut (Brosimum alicastrum): Comparison with commercial nuts. Int J Food Prop 2017, 20 (11): 2772-2781. https://doi.org/10.1080/10942912.2016.1252389

4. Cabral CE, Klein MRST. Phytosterols in the Treatment of Hypercholesterolemia and Prevention of Cardiovascular Diseases. Arq Bras Cardiol. 2017, 109(5): 475 - 482. https://doi.org/10.5935/abc.20170158 
5. Teodoro AJ. Bioactive Compounds of Food: Their role in the prevention and treatment of Diseases. Oxid. Med. Cell. Longev, 2019 Article ID 3765986, https://doi.org/10.1155/2019/3765986

6. Hejtmankova A, Taborsky J, Kudelova V, Kratochvilova K. Contents of tocols in different types of dry shell fruits. Agro Res 2018, 16(S2): $1373-1382$. https://doi.org/10.15159/AR.18.148

7. Olatunya AM, Olatunya OS, Akintayo ET. Potential health and economic benefits of three locally grown nuts in Nigeria: implications for developing countries. Heliyon 2017, 3 (10): 2017. https://doi.org/10.1016/j.heliyon.2017. e00414

8. Peter S, Chopra S, Jacob JJ. A fish a day keeps the cardiologist away - a review of the effect of omega 3 fatty acids in the cardiovascular system. India J Endocrinol Metab (2013); 17 (3): 422-429. https://doi.org/10.4103/2230-8210.111630

9. Are Cashews Good for You? Nutrition, Benefits, and Downsides. [https://www.healthline.com/nutrition/arecashews-good-for-you] Retrieved August 27, 2021.

10. Ryan E, Galvin K, O'Connor TP, Maguire AR, O'Brien NM. Fatty acid profile, tocopherol, squalene and phytosterol content of brazil, pecan, pine, pistachio and cashew nuts. Int J Food Sci Nutr 2006, 57(3/4): 219- 228. https://doi.org/10.1080/09637480600768077

11. Guasch-Ferré M, Liu X, Malik VS, Sun Q, Willett WC, JoAnn E, Manson JE, Rexrode KM, Li Y, Hu FB, Bhupathiraju SN. Nut Consumption and Risk of Cardiovascular Disease. J Am Coll Cardiol 2017, 70(20): 2519-2532. https://doi.org/10.1016/j.jacc.2017.09.035

12. Provan J, Scobbie L, Chesson A. Determination of phenolic acids in plant cell walls by microwave digestion. J Sci Food Agric 1994, 64: 63-65. https://doi.org/10.1002/jsfa.2740640110

13. Du M, Ahn DU. Simultaneous analysis of tocopherols, cholesterol, and phytosterols using gas chromatography. J. Food Sci 2002, 67: 1696-1700. https://doi.org/10.1111/j.1365-2621.2002.tb08708.x

14. Ahsan $\mathrm{H}$, Ahad A, Siddiqui WA. A review of characterization of tocotrienols from plant oils and foods. J Chem Biol 2015, 8: 45-59. 10.1007/s12154-014-0127-8

15. International Organization for Standardization ISO. (1998) Oilseeds: determination of hexane extract (or light petroleum extract), called oil content. https://www.iso.org/obp/ui/\#iso:std:iso:659:ed-4:v1:en Retrieved December 27, 2021
16. Choubey S, Varughese L, Kumar V, Beniwal V. Medicinal importance of gallic acid and its ester derivatives: a patent review. Pharm Pat Anal 2015, 4:305-315.

https://doi.org/10.4155/ppa.15.14

17. Kahkeshani N, Farzaei F, Fotouhi M, Alavi SSH, Bahramsoltani R, Naseri R, Momtaz S., Abbasabadi Z, Rahimi R, Farzaei MH, Bishayee A. Pharmacological effects of gallic acid in health and diseases: A mechanistic review. Iran J Basic Med Sci. 2019, 22: 225-237. https://doi.org/10.22038/ijbms.2019.32806.7897

18. Ruwizhi N, Aderibigbe BA. Cinnamic Acid Derivatives and Their Biological Efficacy. Int J Mol Sci 2020, 21: 5712. https://doi.org/10.3390/ijms21165712

19. Jang SA, Song HS, Kwon JE, Baek HJ, Koo HJ, Sohn E, Lee SR, Kang SC. (2018). Protocatechuic Acid Attenuates Trabecular Bone Loss in Ovariectomized Mice. Oxid Med Cell Longev. 2018. https://doi.org/10.1155/2018/7280342

20. Touaibia M, Jean-Francois J, Doiron J. Caffeic acid, a versatile pharmacophore: an overview. Mini-Rev Med Chem 2011, 11: 695-713.

https://doi.org/10.2174/138955711796268750

21. Damasceno SS, Dantas BB, Ribeiro-Filho J, Antônio M, Araújo D, Galberto M, Costa J. Chemical properties of caffeic and ferulic acids in biological system: implications in cancer therapy. a review. Curr Pharm Des 2017, 23: 3015-3023. https://doi.org/ 10.2174/1381612822666161208145508

22. Sales MJ, Resurreccion AVA. Phenolic profile, antioxidants, and sensory acceptance of bioactive-enhanced peanuts using ultrasound and UV. Food Chem 2010, 122: 795-803. https://doi.org/10.1016/j.foodchem.2010.03.058

23. Kornsteiner M, Wagner K, Elmadfa I. Tocopherols and total phenolics in 10 different nut types. Food Chem 2006, 98: 381-387. https://doi.org/10.1016/j.foodchem.2005.07.033

24. Zingg JM. Modulation of signal transduction by vitamin $\mathrm{E}$. Mol Asp Med 2007, 28, 418 - 506. https://doi.org/ $\underline{10.1016 / \text { j.mam.2006.12.009 }}$

25. Olatunya AM, Omojola A, Akinpelu K, Akintayo ET. Vitamin E, phospholipid and phytosterol contents of Parkia biglobosa and Citrullus colocynthis seeds and their potential applications to human health. Prev Nutr Food Sci 2019, 24 (3): 338 - 343. https://doi.org/10.3746/pnf.2019.24.3.338

26. Takahashi K, Loo G. Disruption of mitochondria during tocotrienol-induced apoptosis in MDA-MB-231 human breast cancer cells. Biochem Pharm 2004, 67 :315-324. https://doi.org/10.1016/j.bcp.2003.07.015 
27. Lewis ED, Meydani SN, Wu D. Regulatory role of vitamin E in the immune system and inflammation IUBMB Life 2019, 71(4): 487-494. https://doi.org/10.1002/iub.1976

28. Brigelius - Flohe R, Traber MG. Vitamin E: function and metabolism. FASEB J 2019, 13: 1145- 1155.

https://doi.org/10.1096/fasebj.13.10.1145

29. Vitamin E WebMD medical reference.

[https://www.webmd.com/diet/supplement-guidevitamin-e\#2] Retrieved August 13, 2021

30. Silva MP, Martinez MJ, Casini C, Grosso NR. Tocopherol content, peroxide value and sensory attributes in roasted peanuts during storage. Int J Food Sci Tech 2010, 45:14991504. https://doi.org/10.1111/j.1365-2621.2010.02293

31. Rico R, Bulló $M$, Salas-Salvadó J. Nutritional composition of raw fresh cashew (Anacardium occidentale L.) kernels from different origin. Food Sci Nutr 2016, 4(2): 329-338.

https://doi.org/10.1002/fsn3.294

32. Dietary Guidelines for Americans 2015 - 2020 (8 $8^{\text {th }}$ edition).[https://www.dietaryguidelines.gov/sites/default/f iles/2020-12/Dietary Guidelines for Americans 2020-

2025.pdf] Retrieved August 27, 2021

33. Lampi AM, Nurmi T, Ollilainen V, Piironen V. Tocopherols and tocotrienols in wheat genotypes in the health grain diversity screen. J Agric Food Chem 2008, 56 (21): $9716-$ 9721. https://doi.org/10.1021/jf801092a

34. Parraga - Martinez I, Lopez - Torres - Hidalgo JD, Del campoDel campo JM, Galdon - Blesa MP, Precious-Yanez JC, Sotos RL, Ramos MGR, Pretel FA, Bravo BN, Callejo AL. Long-term effects of plants stanols on the lipid profile of patients with hypercholesterolemia. A randomized clinical trial. Rev Esp Cardiol 2015, 68(8): 665-671.

https://doi.org/10.1016/rec.2014.07035

35. Ras RT, Fuchs D, Koppenol WP, Garczarek U, Greyling A, Keicher C, Verhoeven C, Bouzamondo H, Wagner F, Trautwein EA. The effect of a low -fat spread with added plant sterols on vascular function markers: results of the investigating vascular function effects of plant sterols (INVEST) study. Am. J. Clin. Nutr 2015, 101(4): 733-741. https://doi.org/10.3945/ajen.114.102053 